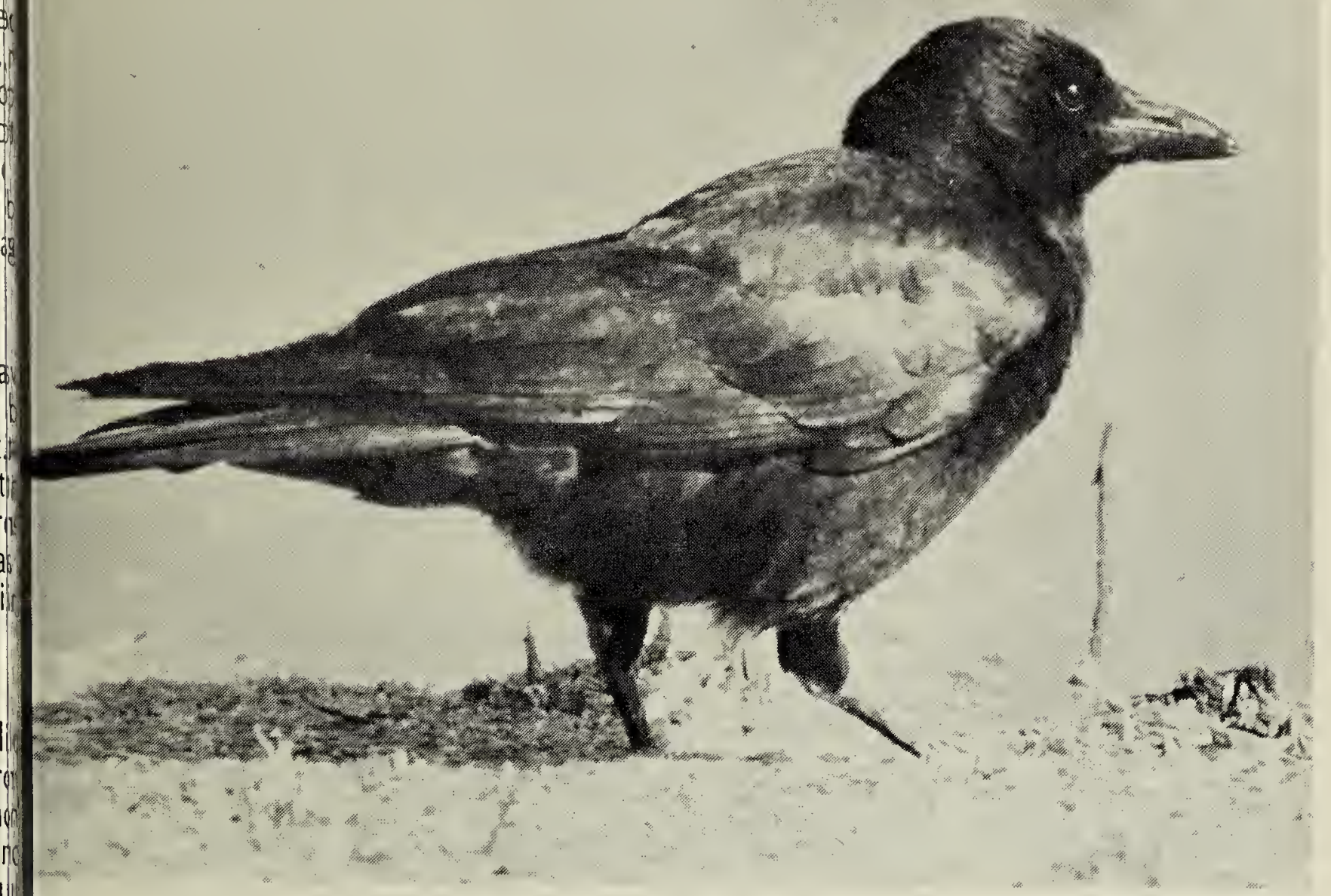

non Crow

Fred Lahrman

\title{
CROWS SAY CAW?
}

\section{DR C. FRIESEN, Box 65, Rosthern, Saskatchewan SOK 3R0}

a commonplace that crows say Thus Taverner says nothing of ry of our Common Crow but merely to its "familiar voice."12 rly, Chapman includes the voice as one of its traits which to make the crow the "best of our birds." The voice is a ,open caw," he says, and he aply has listened to it carefully, distinguishes this sound from ade by another member of the dae family, the Fish Crow. ${ }^{3}$ ers made the same distinction till described the Common s voice as "caw", "cah" or "ca-

trouble with this commonplace from my childhood, some 35 ago, I could never once hear crow says caw. To my ear it says ith an explosive initial vowel, it but the $c$ is just not present. I mentioning this fact to one of deschool teachers in the 1940's and, since that time, to some other bird watchers. Upon close listening, they have agreed with what I have heard. Meanwhile, because I grew up on a farm and continue to live there each summer, I have had ample opportunity to continue to hear crows cawing-or, rather, "awing."

A few years ago I spent a good part of an afternoon playing and replaying Band 1, Side 4 of $A$ Field Guide to Western Bird Songs ${ }^{6}$ to someone with a trained musical ear. Although we played the record at various speeds, neither of us could hear the initial $c$ of the crow's caw.

Lately I have been examining again the comments about crows in present-day bird guides. My own observations (that is, auditions) seem to receive little support. Peterson says crows make a "loud caw or cah or kahr, easily imitated"8; Pough speaks of their "ca-ah, ca-ah, ca-ah" known 


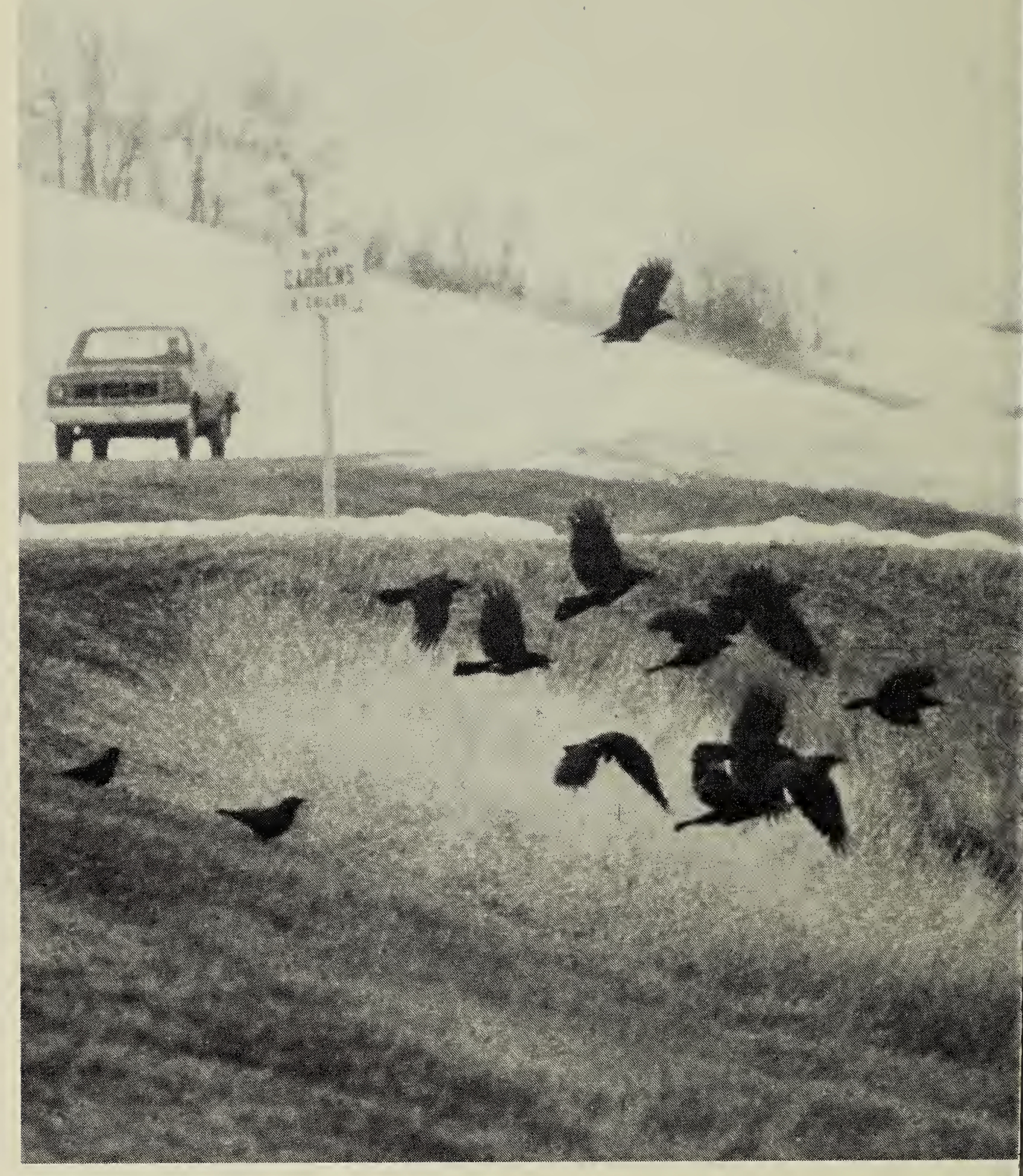

Migrating crows

Gary W

by everyone ${ }^{10}$; and Godfrey writes of their "familiar caw."

Even authors concerned solely with bird songs refer to crows' cawing in a similar manner. Although Mathews takes pains to shatter one commonplace about crows (that their color is not black but rather an iridescent steel-blue!) he hears their cry-whether it be a "cr-r-r-r-r-uck," a "caw, caw, caw," or a "ca-cak-ca-

caw"-always beginning witt consonant c. He then gives musical notation of these calls of treble clef.

In another such study Arms cites the mimic qualities of our $\mathrm{C}$ Old World cousins, the Carrion the Hooded Crow, and the $\mathrm{R}$ These birds, according to Pete Mountfort and Hollom, have calls of "kraa" or "kaw." Sinc 
start with a $k$-sound, could it be ible that when immigrants came ur land and first saw our native $v$ they simply assumed, or hearing tat it too said a kind of caw?

f course, crows are quite capable ying caw. Forbush and May have ted out that crows have the $x$ of a singer and so can produce riety of sounds, including a dog's le, a hen's squawk, or a rooster's ving. ${ }^{4}$ Bent refers to their erior imitative faculties" and ability to mimic human sounds. ${ }^{2}$ y farm boys, indeed, have had rows that could talk. And talking $s$, or their relatives, have become of our folklore-from "The Twa ies" of the medieval English d who discuss their plans to pick the bones of knights slain in - - to the crows, three in number time, of the toned-down rican folksong "Billy Magee aw," where the birds choose to on slain horse. Here the birds say three times before repeating the 's title. Certainly, crows can c a caw as well as human speech.

nt goes on to quote several sentative authors in order to us a well-rounded concept of $\mathrm{s}^{\prime}$ cawing. $^{2}$ Again, the writers listened closely, for we learn Allen about the rhythm of the from Wright about the times of first being voiced each morning; Hoffmann, Knight, and Forbush $t$ the accents placed on various to indicate the meaning of that d. Only Townsend, writing rally in 1923, speaks of such commodifications of the crow's call $r$, orr" and "ou, ahh, ahh, ahh," le with my own experience. send continues: "The converhal notes of a small group or of Crows are always enter$\mathrm{g}$, and the observer is impressed the extensiveness of their ulary and the variations in their gs."

that the Common Crow is is in numbers once more at the of this summer season, the rs of the Blue Jay might well again with fresh ears to what the bird is in fact saying, keeping in mind that

To be a fine student of ornithology And study our crows and their philology

Is to listen to them caw,

To oneself say, "Ah-hah!

This subject is surely one of phonology."

If crows normally do utter both a caw and an aw, which call is the more prevalent?

'ARMSTRONG, E. A. 1973. A study of bird song. Dover, New York, (pp. 81, 83, 110).

${ }^{2}$ BENT, A. C. 1964. Life histories of North American jays, crows, and titmice, part II. Dover, New York (republication of U.S. Nat. Mus. Bull. 191), (pp. 247-249).

${ }^{3}$ CHAPMAN, F. M. 1966. Handbook of birds of eastern North America. Dover, New York, (pp. 391-392).

${ }^{4}$ FORBUSH, E. H., and 1. B. MAY, 1939. A natural history of American birds of eastern and central North America. Houghton Mifflin, Boston, (pp. 344-345).

${ }^{5}$ GODFREY, W. E. 1966. The birds of Canada. Nat. Mus. of Canada Bull. 203, Ottawa, (p. 275). (428 pp.).

${ }^{6}$ Laboratory of Ornithology, Cornell University. 1962. A field guide to western bird songs ( 3 records). Houghton Mifflin, Boston.

7 MATHEWS, F. S. 1967. Field book of wild birds and their music. Dover, New York, (p. 47).

${ }^{8}$ PETERSON, R. T. 1961. A field guide to western birds. Houghton Mifflin, Boston, (p. 210). (366 pp.).

${ }^{9}$ PETERSON, R. T., G. MOUNTFORT, and P. A. D. HOLLOM (n.d.) A field guide to the birds of Britain and Europe. Houghton Mifflin, Boston, (pp. 197, 200, 202).

${ }_{10} \mathrm{POUGH}, \mathrm{R} . \mathrm{H} .1949$. Audubon land bird guide. Doubleday, Garden City, N.Y., (p. 87). (312 pp.).

${ }^{11 S A U N D E R S, ~ A . ~ A . ~ 1951 . ~ A ~ g u i d e ~ t o ~ b i r d ~}$ songs. Doubleday, Garden City, (p. 105). (307 pp.)

${ }^{12}$ TAVERNER, P. A. 1938. Birds of Canada. Musson, Toronto, (p. 307). (446 pp.) 